Chirurgia (2019) 114: 761-768

No. 6, November - December

Copyright@ Celsius

http://dx.doi.org/10.21614/chirurgia.114.6.761

\title{
Weight Loss and Late Complications after Silastic Ring Vertical Gastroplasty. A 10 Year Follow-up
}

\author{
Adriana Florinela Cătoi', Romeo Florin Galea $^{2}$, Cristina Bidian ${ }^{3}$, Daniela Ciobârcă ${ }^{4}$ \\ 'Department of Physiopathology, Faculty of Medicine, "Iuliu Hatieganu” University of Medicine and Pharmacy, Cluj-Napoca \\ ${ }^{2}$ Second Surgical Clinic, Department of Surgery, Faculty of Medicine, "Iuliu Hatieganu" University of Medicine and Pharmacy, Cluj-Napoca \\ ${ }^{3}$ Department of Physiology, Faculty of Medicine, "Iuliu Hatieganu" University of Medicine and Pharmacy, Cluj-Napoca \\ ${ }^{4}$ Department of Bromatology, Hygiene, Nutrition, Faculty of Pharmacy, "luliu Hatieganu” University of Medicine and Pharmacy, Cluj-Napoca
}

Corresponding author:

Adriana Florinela Cătoi, MD

Department of Physiopathology

Faculty of Medicine

„Iuliu Hatieganu” University

of Medicine and Pharmacy

Cluj-Napoca, Romania

E-mail: adriana.catoi@umfcluj.ro

Abbreviations:

SRVG - silastic ring vertical gastroplasty;

BMI - body mass index;

$S G$ - are sleeve gastrectomy;

RYGB - Roux-en-Y gastric bypass.
Received: 03.11.2019

Accepted: 16.12 .2019

\section{Rezumat}

Reducerea ponderală și complicațile tardive asociate cu gastroplastia verticală cu inel de silicon. Rezultate la 10 ani postoperator

Scopul lucrării: Obezitatea severă constituie o problemă serioasă de sănătate publică, chirurgia bariatrică reprezentând unicul tratament eficient al acesteia. Printre procedeele chirurgicale bariatrice, gastroplastia verticală cu inel de silicon (SRVG) s-a impus ca o metodă restrictivă sigură, care a fost utilizată cu succes în trecut. Actualmente, SRVG a fost abandonată în favoarea unor procedee laparoscopice. Scopul prezentului studiu a fost acela de a investiga efectul SRVG asupra reducerii ponderale, precum şi instalarea complicațiilor tardive sau efectuarea reintervenților chirurgicale în cazul unui lot de pacienți cu obezitate severă, pe o perioadă de urmărire postoperatorie de 10 ani.

Material şi Metode: Am efectuat o analiză retrospectivă pe un lot de 112 pacienți cu obezitate severă care au fost supuşi intervenției de SRVG deschis, între anii 2008-2009, urmărind atât evoluția indicelui de masă corporală (IMC) şi a procentajului IMC pierdut (\%EBMIL), cât şi aparitia complicatiilor chirurgicale tardive sau efectuarea reinterventiilor chirurgicale. $41,96 \%$ dintre pacienți au rămas înrolați în studiu după 10 ani.

Rezultate: Media inițială a IMC de $47,38 \pm 7,59 \mathrm{~kg} / \mathrm{m}^{2} \mathrm{~s}$-a redus semnificativ statistic ( $<00,001)$ în primul an după SRVG până la $31,05 \pm 6,54 \mathrm{~kg} / \mathrm{m}^{2}$. Valoarea IMC s-a menținut relativ stabilă în primii 5 ani postoperator, crescând apoi progresiv până la 35,93 \pm $7,20 \mathrm{~kg} / \mathrm{m}^{2}$ în al 10-lea an de monitorizare, dar rămânând, totuşi, 
semnificativ scăzută $(p<0,001)$ în comparație cu nivelul inițial. EBMIL\% a atins $79 \%$ la un an după SRVG şi a ajuns la 51\% la finalul perioadei de urmărire. Printre cele mai frecvente complicații tardive s-au numărat stenoza stomei (8,92\%), lărgirea stomei $(8,03 \%)$ şi hernia incizională $(3,36 \%)$. Apariția stenozei a impus eliminarea inelului. În 2 cazuri, după îndepărtarea inelului, pacienții au fost supuşi intervenției de bypass gastric.

Concluzii: SRVG reprezintă un procedeu chirurgical sigur şi eficace, pretabil la diverse reintervenții, fiind asociat cu reducerea semnificativă a excesului ponderal şi menținerea pe termen lung. Stenoza stomei, lărgirea stomei şi hernia incizională reprezintă cele mai frecvente complicații tardive ale SRVG care reclamă reintervenții.

Cuvinte cheie: SRVG deschis, reducere ponderală, complicații tardive, reintervenții chirurgicale, 10 ani de urmărire postoperatorie

\begin{abstract}
Background and aim: Severe obesity is a public health care system challenge that requires bariatric surgery. Among the plethora of bariatric surgery techniques silastic ring vertical gastroplasty (SRVG) is a safe and efficient restrictive method that has been successfully used previously. However, it's performance by open approach has been abandoned and replaced by other methods using the laparoscopic method. The aim of the present study was to investigate patients with severe obesity submitted to open SRVG and to report our results over a period of 10 years in terms of weight loss, late complications and surgical re-interventions.

Material and methods: 112 severely obese patients submitted to open SRVG between years 20082009 were investigated retrospectively for body mass index (BMI), percent excess BMI loss (\%EBMIL), late surgical complications and reoperations. $41.96 \%$ of the patients were followed up 10 years after SRVG.

Results: The initial mean BMI was $47.38 \pm 7.59 \mathrm{~kg} / \mathrm{m}^{2}$ and dropped statistically significant $(\mathrm{p}<0.001)$ to $31.05 \pm 6.54 \mathrm{~kg} / \mathrm{m}^{2}$ by the first year after SRVG. The mean BMI was rather stable along the first 5 years after SRVG when it started to increase gradually, reaching $35.93 \pm 7.20 \mathrm{~kg} / \mathrm{m}^{2}$ by the $10^{\text {th }}$ year of follow-up when it remained still significantly lower $(\mathrm{p}<0.001)$ as compared to the mean baseline value. The $\%$ EBMIL was $79 \%$ at one year after surgery and reached $51 \%$ by the $10^{\text {th }}$ year of follow-up. The most frequent late complications after SRVG were stoma stenosis (8.92\%), enlargement of the stoma (8.03\%) and incisional hernia (3.36\%). As a consequence of stoma stenosis the ring has been removed in all cases. In 2 cases, after the ring removal, the patients underwent gastric bypass.

Conclusion: SRVG is a safe and efficient restrictive technique of bariatric surgery open to many options to be revised, leading to a successful sustained long term weight loss and maintenance. Stoma stenosis, enlargement of the stoma and incisional hernia are the most frequent late complications after SRVG requesting reoperations.
\end{abstract}

Key words: open SRVG, weight loss, late complications, surgical reinterventions, 10-year follow-up

\section{Introduction}

Obesity is a chronic disease known to be a real challenge to both patients and public health care systems (1). Patients with severe obesity, i.e. body mass index (BMI) over $40 \mathrm{~kg} / \mathrm{m}^{2}$ or over $35 \mathrm{~kg} / \mathrm{m}^{2}$ with comorbidities such as type 2 diabetes, dyslipidemia or hypertension, face the problem of attaining significant weight loss and mostly of maintaining the gained weight. Therefore, for these categories of patients, bariatric surgery is the only recog- 
nized long-term effective treatment (2,3). Also, besides weight loss, bariatric surgery holds an important role in reducing the obesity associated diseases and thus in restoring health, improving life quality, and in increasing the lifespan $(1,4)$. Indeed, due to the obesity epidemic and to the increasing safety of bariatric surgery, it has boosted up worldwide more than 10 fold in the past 20 years (5).

The success of a bariatric procedure is evaluated in terms of long term results, i.e. significant weight loss and maintenance, remission/amelioration of comorbidities as well as rate of complications (6). Historically, bariatric surgery encompasses a wide gamut of techniques, i.e. over 50 operations, showing that the field of obesity surgery is a work in progress and that the best operation has yet to be discovered (4). Currently, the most performed techniques are sleeve gastrectomy (SG) (45.9\%) and Roux-en-Y gastric bypass (RYGB) (39.6\%) performed by minimally invasive surgery (2). Still, every operation has its own complications and failures and, therefore, a long term follow-up is mandatory $(7,8)$.

Silastic ring vertical gastroplasty (SRVG) developed by Eckhout is based on the original vertical banded gastroplasty created by Mason in $1982(9,10)$. It is a restrictive procedure that has been successfully used in Cluj-Napoca, Romania, since 1997 when this bariatric method was firstly performed in our country (11). However, later, due to the development of the laparoscopic surgical approach, open SRVG has faded away and lost popularity, finally being replaced by other minimally invasive bariatric procedures.

Within this study we aimed to investigate patients with severe obesity submitted to open SRVG and to report 10-year results in terms of weight loss, late complications and surgical reinterventions.

\section{Material and Methods}

\section{Patients and study design}

This retrospective study included 112 severely obese patients that underwent open SRVG between years 2008-2009 and that were recruited consecutively from our dataset. All the patients fulfilled the criteria for bariatric surgery, i.e. body mass index over $40 \mathrm{~kg} / \mathrm{m}^{2}$ or $35-40 \mathrm{~kg} / \mathrm{m}^{2}$ with at least one comorbidity and previously failed attempts to lose weight and/or to maintain a healthy weight. Patients that lacked an identifiable medical management of obesity, those who were unable to participate to the post-surgical follow-up and to care for themselves as well as those who were known with psychiatric disorders, alcohol abuse and/or drug dependencies and diseases threatening life in the short term were not accepted for bariatric surgery $(12,13)$.

Preoperative assessment consisted in an interview on the dietary habits, history of the disease (obesity) and of other comorbidities as well as anthropometric and routine laboratory measurements. The post-surgery follow-up consisted in visits at the clinic that involved anthropometric and routine biochemical evaluations at 1, 3, 6, 12 months and then yearly over a period of 10 years. The length of the hospitalization stay, postoperative late complications and mortality were also investigated. After the surgery the patients were recommended to use vitamin and mineral supplementation. The follow-up was not completed by all the operated patients. In these cases we used the telephone interview in order to update our database regarding weight evolution and general health status, including complications and reoperations. Nevertheless, some of the patients were lost during the 10year survey.

\section{Anthropometric and Laboratory Measurements}

Body mass index (BMI) was calculated by using the ratio weight $(\mathrm{kg}) /$ height $\left(\mathrm{m}^{2}\right)$. Percent excess BMI loss (\%EBMIL) was calculated according to the [(initial BMI- final BMI)/(initial BMI-25)] x 100 formula (14). Success was defined as EBMIL $>50 \%$. The laboratory measurements were performed by standard methods and involved routine parameters. 


\section{Surgical Intervention}

All patients were submitted to open SRVG that was performed by the same surgeon. The clinical setting was the Second Surgical Clinic from "Iuliu Hațieganu" University of Medicine and Pharmacy, Cluj-Napoca. SRVG is a restrictive procedure that does not involve gastric resection. The stomach is vertically divided into 2 compartments from the Hiss angle over a $9 \mathrm{~cm}$ distance by mechanical suture with titanium clips. A $5.3 \mathrm{~cm}$ silicon ring is fixed at the base of this suture. The two compartments are separated by a 12 diameter opening and consist in an upper pouch of approximately $70 \mathrm{ml}$ and a lower pouch representing the rest of the stomach (15-17).

\section{Statistical Analysis}

Continuous variables with normal distribution were expressed using descriptive statistics as mean \pm standard deviation. The paired Student t-test was used to study the changes of the analyzed parameters at every time point after surgery. The statistical significance was set at the $\mathrm{p}$-value $<0.05$.

\section{Results}

The baseline characteristics of the patients are presented in Table 1. The hospitalization duration was between 5 and 7 days. Out of the 112 patients with severe obesity, 47 (41.96\%) were followed-up 10 years after open SRVG.

The initial mean BMI was 47.38 \pm 7.59 $\mathrm{kg} / \mathrm{m}^{2}$ which dropped statistically significant $(p<0.001)$ to $31.05 \pm 6.54 \mathrm{~kg} / \mathrm{m}^{2}$ by the first year after SRVG. The mean BMI was $30.11 \pm 6.47$

Table 1. Baseline characteristics of the severely obese patients candidates for SRVG

\begin{tabular}{lc}
\hline Mean age & $37.61 \pm 10.77$ \\
\hline Sex & $88 \mathrm{~F} / 24 \mathrm{M}$ \\
\hline Mean BMI $\left(\mathrm{kg} / \mathrm{m}^{2}\right)$ & $47.38 \pm 7.59$ \\
\hline Comorbidities & \\
$\quad$ Type 2 diabetes & $25(22.32 \%)$ \\
Hypertension & $14(12.5 \%)$ \\
Coronary heart disease & $3(2.67 \%)$ \\
\hline
\end{tabular}

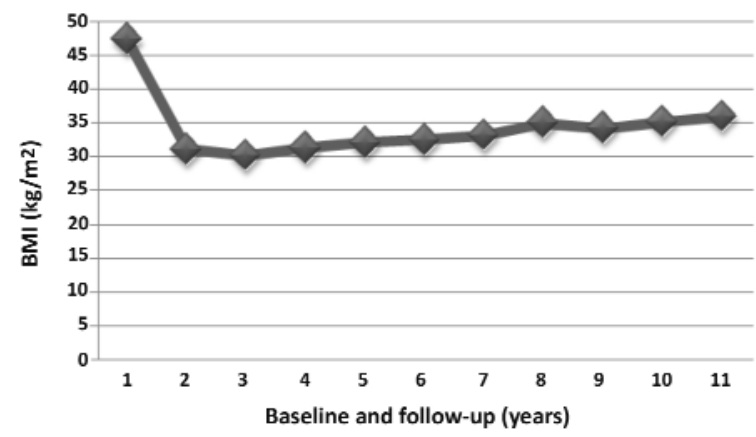

Figure 1. The 10-year dynamics of BMI after open SRVG

$\mathrm{kg} / \mathrm{m}^{2}$ by the second year, $31.28 \pm 5.94 \mathrm{~kg} / \mathrm{m}^{2}$ by the third year, $32.07 \pm 5.45 \mathrm{~kg} / \mathrm{m}^{2}$ by the fourth year and it was maintained during the fifth year to $32.48 \pm 5.77 \mathrm{~kg} / \mathrm{m}^{2}$. From this time point on, BMI started to increase slightly, reaching $33.20 \pm 6.08 \mathrm{~kg} / \mathrm{m}^{2}$ by the sixth year and, finally, $35.93 \pm 7.20 \mathrm{~kg} / \mathrm{m}^{2}$ by the tenth year. However, at the tenth year of follow-up, the mean BMI was still significantly lower $(p<0.001)$ as compared to the baseline values (Fig. 1). The \%EBMIL was $79 \%$ at one year after surgery and reached $51 \%$ by the 10th year of follow-up (Fig. 2).

In terms of comorbidities, patients with type 2 diabetes and hypertension became free of medication by the end of the first year after SRVG.

The most frequent late complications after open SRVG were stoma stenosis (8.92\%), enlargement of the stoma $(8.03 \%)$ and incisional hernia $(3.36 \%)$. As a consequence of stoma stenosis the ring has been removed in all these patients. In 2 cases, after the ring

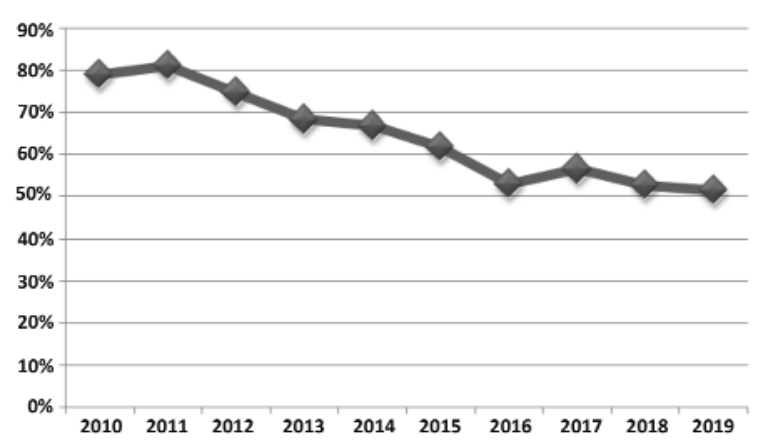

Figure 2. The dynamics of \%EBMIL along the 10-year follow-up after open SRVG 
removal, the patients underwent gastric bypass. There was no surgery related mortality recorded during the follow-up.

\section{Discussion}

Open SRVG is a safe and efficient restrictive technique that has been successfully performed in the Second Surgical Clinic of "Iuliu Hațieganu" University of Medicine and Pharmacy of Cluj-Napoca. Between 1997 and 2013 (when open SRVG has been replaced by other methods), 1080 operations have been performed using this surgical procedure. Within this framework 112 patients submitted to open SRVG between years 2008-2009 were collected form our database in a consecutively manner with the aim to investigate the long term results of the surgery, along a period of 10 years, in terms of weight loss, complications and re-interventions. Herein, we show that open SRVG is an effective surgical procedure by resulting in important and sustainable weight loss. We are aware of the fact that the complete follow-up is rather low, but still we are able to report some significant results. The lack of complete follow-up may be attributable, in our opinion, at least to some extent, to the well-being of the patients after surgery as well as to the difficulties in reaching the Clinical Center (distance). In fact, an optimal follow-up has been demonstrated to be a challenge for other researchers as well (18). Other studies involving SRVG reported a complete follow-up of $71 \%$ along $7.1 \pm 3$ years (range 4 to 16 years) and $78 \%$ in a surveillance of at least 6 years $(6$ to 11) $(19,20)$. Finally, in a very recent report of a prospective longitudinal cohort study of patients who underwent laparoscopic adjustable gastric banding (LAGB) as a primary bariatric procedure showed a $39 \%$ follow-up at 10 years after surgery which is very similar to our survey (21).

The mean baseline BMI of the severely obese patients was $47.38 \pm 7.59 \mathrm{~kg} / \mathrm{m}^{2}$. We noted that the most important weight loss took place within the first year after open SRVG, when the mean BMI reached a signifi- cant reduction to $31.05 \mathrm{~kg} / \mathrm{m}^{2}$. In terms of BMI dynamics we observed that the BMI value was relatively maintained during the following 4 years $\left(32.48 \mathrm{~kg} / \mathrm{m}^{2}\right.$ by the $4^{\text {th }}$ year), when it slightly started to increase, reaching a mean value of $35.93 \mathrm{~kg} / \mathrm{m}^{2}$ by the end of the $10^{\text {th }}$ year of follow-up. Our results are comparable with those reported by Paran et al. (19) who studied 115 patients undergoing SRVG and showed a reduction from a BMI of 47 to $29 \mathrm{~kg} / \mathrm{m}^{2}$ within the first year after the operation. Moreover, similarly, following this time point, they reported a gradual, but still acceptable, increase in BMI, reaching $35 \pm 4 \mathrm{~kg} / \mathrm{m}^{2}$ at 10 years following surgery (19). In line with these results, Closset et al. (20) reported a decrease of the mean BMI from $45.3 \mathrm{~kg} / \mathrm{m}^{2}$ to 30.7 $\mathrm{kg} / \mathrm{m} 2$ in 213 patients followed for at least 6 years (6 to 11) or until reoperation was needed. The peak of the weight loss observed by the second year $\left(30.11 \pm 6.47 \mathrm{~kg} / \mathrm{m}^{2}\right)$ of follow-up in our patients goes hand in hand with the results reported by O'Brien et al. (21) who analyzed obese patients submitted to LAGB along a period of 20 years after surgery. Furthermore, the authors reported a relatively stable weight loss from that time point to 20 years. A slight weight regain after bariatric surgery has been documented after other procedures as well $(22,23)$. Chang et al. (18) reported a thirteen-year experience with laparoscopic SG and showed that the maximal weight loss was achieved at 1 year followed by small weight regain subsequently. Thomas et al. (24) reported in patients that underwent RYGB that once the nadir is reached, a period of weight regain in the next 1 to 4 years is installed which, subsequently, is followed by a "relatively stable" weight period.

In our study, by the first year after surgery the $\%$ EBMIL reached $79 \% \pm 26 \%$, but this value decreased gradually along the 10 year follow-up and reached $51 \% \pm 31 \%$ by the end of the follow-up. Paran et al. (19) reported similar results, i.e. a \%EBMIL $67 \pm 19 \%$ one year after surgery. Although open SRVG is no longer performed, when searching within the literature for long term results with other techniques that are used at present we 
observed that the outcomes are comparable. Indeed, a very recent systematic review with meta-analysis on reports containing 10 or more years of follow-up after bariatric surgery showed a mean \% excess weight loss (\%EWL) of $56.7 \%$ after gastric bypass, $58.3 \%$ after SG, $45.9 \%$ after LAGB, and $74.1 \%$ after biliopancreatic bypass +/- duodenal switch (21). Noteworthy, this review included the only two at the moment available reports on long term results of SG, and therefore more studies are warranted to shed light on the weight loss outcome after SG. Another study that followed 3566 patients up to 20 years after LAGB showed a \%EWL of $49 \%$ at 10 years after the surgery (25). Altogether, these data show that SRVG induces a significant durable weight loss which is similar to the effect produced by LAGB. Gastric bypass that combines restriction with malabsorption induces a slightly higher weight loss similar to SG as compared to SRVG. However, with regard to SG the small number of long term studies prevents us of drawing a final conclusion on its weight loss long term outcome.

Closset et al. (20) reported SRVG as a safe procedure. Indeed, we had no mortality in our sample of patients, which is similar to other reports $(19,26)$. With regard to late complications, we reported $8.92 \%$ cases of stoma stenosis which led to excessive weight loss and severe vomiting that required ring removal. In some cases, the stenotic ring was replaced with a new ring, while in other cases the patients underwent gastric bypass. Also, other most frequent late complications after SRVG were incisional hernia and enlargement of the stoma which resulted in significant weight regain. Likewise, Closset et al. (20) reported outlet stoma stenosis in $14 \%$ of patients, possibly as the main problem of SRVG (27) and incisional hernia. Paran et al. (19) pointed out towards stenosis of the pouch outlet as a consequence of stricture at the ring, failure of the staple-line as well as ventral hernias as main late post SRVG complications, all requiring re-operations. SRVG is a procedure that is open to many options to be laparoscopically revised. However, the conversion of SRVG into other techniques stands out in its difficulty and the decision regarding which method should be carried out in case of failed SRVG (due to excessive weight loss or weight regain) represents a real challenge $(28,29)$. Some authors reported conversion to LAGB as a consequence of disruption of the staple-line and pouch dilatation accompanied by frequent vomiting $(19,30)$. On the other hand, Elazary et al. (31) reported a higher rate of complications after SG as a revisional procedure compared to RYGB resulting in the decision to stop the conversion into SG and highlighting that RYGB is a safer choice. Finally, Abu-Gazala et al. showed that a feasible and effective method to convert failed SRVG would be the biliopancreatic diversion (BPD) (29).

Other procedures are accompanied as well by late complications that need re-do surgery. Chang et al. (18) reported reflux esophagitis as the most common cause for revision after SG followed by important weight regain. This latter condition was suggested to be attributable to gastric tube dilatation or to a "shift" of the dietary habits towards sweets (32). Finally, at 10 years the authors reported the revision rate of $21.5 \%$ and the conversion rate to RYGB of $16.9 \%$.

Complications have been reported also after LAGB such as pouch herniation-dilation $(5.8 \%)$ and erosion $(2.5 \%)$ with a total reoperation rate of $24.1 \%$ and conversion into other bariatric procedures in $3.2 \%$ cases (25).

The pre- and post-SRVG eating behavior influences the weight loss outcome $(26,33)$. Often, patients tolerate less red meat and have the tendency to ingest high amounts of sweet foods and beverages that decrease the process of weight loss or induce weight regain. Weight regain after SRVG may be attributable to the progressively larger amounts of food ingested by the patients that finally result in the dilatation of the proximal pouch, disruption of the staple line and enlargement of the ring. Altogether, these factors increase the compliance for food, leading to weight increase after weight loss (34). Finally, it is important to note that in all bariatric surgery techniques the eating behavior is an important factor that 
influences the long term success of the surgery, and therefore it calls for a rigorous follow-up (18).

We acknowledge that the present study has some limitations. The retrospective small cohort of patients as well as the low follow-up rate call for our caution when interpreting the conclusions. Nevertheless, within the literature the reported data on long term follow-up (over 10 years of survey) after bariatric surgery are scant. Therefore, our single center and single surgeon results render us able to conclude that SRVG is an effective restrictive bariatric surgery procedure.

\section{Conclusion}

In conclusion, SRVG is a safe and effective restrictive technique of bariatric surgery. It leads to significant and sustained long term weight loss and maintenance. Late complications after SRVG request re-do operations in order to halt the excessive weight loss or to stop the weight regain. Also, SRVG is open to many options to be revised. However, in the light of the new laparoscopic approach, open SRVG has become less popular and, finally, it was abandoned.

\section{Conflict of Interest}

The authors declare no conflicts of interests.

\section{References}

1. Nguyen NT, Varela JE. Bariatric Surgery for Obesity and Metabolic Disorders: State of the art. Nat Rev Gastroenterol Hepatol. 2017:14(3):160-9.

2. Angrisani L, Santonicola A, lovino P, et al. Bariatric surgery and endoliminal procedure: IFSO worldwide survey 2014. Obes Surg. 2017;27:2279-89.

3. Angrisani L, Santonicola A, lovino P, Formisano G, Buchwald H, Scopinaro N. Bariatric Surgery Worldwide 2013. Obes Surg. 2015; 25(10):1822-32.

4. Buchwald H, Buchwald JN. Metabolic (Bariatric and Nonbariatric) Surgery for Type 2 Diabetes: A Personal Perspective. Diabetes Care. 2019;42:331-40.

5. Lee W, Almalki 0. Recent Advancements in Bariatric/Metabolic Surgery. Ann Gastroenterol Surg. 2017;171-9.

6. Landecho MF, Valentí V. Eligibility and Success Criteria for Bariatric/Metabolic Surgery. Adv Exp Med Biol. 2017;529-43.

7. Nedelcu M, Khwaja HA, R TG. Weight Regain after Bariatric Surgery - How Should It Be Defined? Surg Obes Relat Dis. 2016;16(5): 1129-1130.
8. Daigle, CR, Brethauer SA, Tu C, Petrick AT, Morton JM, Schauer PR, et al. Which Postoperative Complications Matter Most after Bariatric Surgery? Prioritizing Quality Improvement Efforts to Improve National Outcomes. Surg Obes Relat Dis. 2018;14(5): 652-657.

9. Mason EE. Vertical Banded Gastroplasty for Obesity. Arch Surg. 1982;117(5):701-6.

10. Eckhout GV, Willbanks DL, Moore JT. Vertical Ring Gastroplasty for Morbid Obesity Five Year Experience With 1,463 Patients. Am J Surg 1986; $152: 713$

11. Fried AM, Peskova M, Kasalicky M. Bariatric Surgery in Some "Central and East- European (former Eastern bloc " Countries Current Status and Prediction for the Next Millennium. Obes Surg. 2000;10(3):255-8.

12. Fried M, Hainer V, Basdevant A, Buchwald H, Deitel M, Finer N, et al. Interdisciplinary European Guidelines for Surgery for Severe (Morbid) Obesity. Obes Facts. 2008;1(1):52-9.

13. Fried M, Yumuk V, Oppert JM, Scopinaro N, Torres A, Weiner R, et al. Interdisciplinary European Guidelines on Metabolic and Bariatric Surgery. Obes Surg. 2014;24(1):42-55.

14. Brethauer SA, Kim J, Chaar M, Papasavas P, Eisenberg D, Rogers A, et al. Standardized Outcomes Reporting in Metabolic and Bariatric Surgery. Surg Obes Relat Dis. 2015;11(3):489-506.

15. Galea Fl. Tratamentul chirurgical al obezitatii morbide. Casa Cartii de Stiinta: Cluj-Napoca, 2000; p. 41-50

16. Catoi Galea AF, Duncea I, Galea RF, Coman A. Weight Loss and Comorbidities Reduction One Year after Silastic Ring Vertical Gastroplasty. Cercet Exp Medico-Chirurgicale Anul XVI. 2007; (2-3):128-35

17. Galea RF, Catoi AF. Chirurgia bariatrica si metabolica de restrictie gastrica cu inel si alte proceduri operatorii. Casa Cartii de Stiinta, Cluj-Napoca 2014.

18. Chang DM, Lee WJ, Chen JC, Ser KH, Tsai PL, Lee YC. ThirteenYear Experience of Laparoscopic Sleeve Gastrectomy: Surgical Risk, Weight Loss, and Revision Procedures. Obes Surg. 2018; 28(10):2991-2997

19. Paran H, Shargian L, Shwartz I. Long-term Follow-up on the Effect of Silastic Ring Vertical Gastroplasty on Weight and CoMorbidities. Obes Surg. 2007:17(6):737-41.

20. Closset J, Mehdi A, Barea M, Buedts K, Gelin M, Houben JJ. Results of Silastic Ring Vertical Gastroplasty More Than 6 Years after Surgery: Analysis of a Cohort of 214 Patients. Obes Surg. 2004:14(9):1233-6

21. O'Brien PE, Hindle A, Brennan L, Skinner S4, Burton P, Smith A et al. Long-Term Outcomes After Bariatric Surgery: a Systematic Review and Meta-analysis of Weight Loss at 10 or More Years for All Bariatric Procedures and a Single-Centre Review of 20-Year Outcomes After Adjustable Gastric Banding. Obes Surg. 2019; 29(1):3-14

22. Maciejewski ML, Arterburn DE, Van Scoyoc L, et al. Bariatric surgery and long-term durability of weight loss. JAMA Surg 2016;151:1046-1055

23. Cooper TC, Simmons EB, Webb K, Burns JL, Kushner RF. Trends in weight regain following Roux-en-Y gastric bypass (RYGB) bariatric surgery. Obes Surg 2015;25:1474-1481

24. Thomas DD, Anderson WA, Apovian CM, Hess DT, Yu L, Velazquez A, Carmine B, Istfan NW. Weight Recidivism After Roux-en-Y Gastric Bypass Surgery: An 11-Year Experience in a Multiethnic Medical Center. Obesity (Silver Spring). 2019;27(2):217-225.

25. Furbetta N, Gragnani F, Flauti G, Guidi F, Furbetta F. Laparoscopic Adjustable Gastric Banding on 3566 patients up to 20-year follow-up: long-term results of a standardized technique Surg Obes Relat Dis. 2019;15(3):409-416

26. Vishne TH, Ramadan E, Alper D, Avraham Z, Seror D, Dreznik Z. Long-Term Follow-Up and Factors Influencing Success of Silastic Ring Vertical Gastroplasty. Dig Surg 2004;21:134-141.

27. Alper D, Ramadan E, Vishne T, Belavsky R, Avraham Z, Seror D, et 
al. Silastic Ring Vertical Gastroplasty- Long-term Results and Complications. Obes Surg. 2000;10(3):250-4.

28. Spivak H, Buchholz V, Rubin M. The Laparoscopic Technique of Revision from Silastic Ring Vertical Gastroplasty (SRVG) to Rouxen-Y Gastric Bypass Obes Surg. 2013; 23(8):1107.

29. Abu-Gazala S, Sadot E, Maler I, Golomb I, Carmeli I, Keidar A. Laparoscopic conversion of failed silastic ring vertical gastroplasty (SRVG) and vertical banded gastroplasty (VBG) into biliopancreatic diversion (BPD). J Gastrointest Surg. 2015;19(4): 625-30.

30. Thill V, Khorassani R, Ngongang C, Van De Winkel N, Mendes da Costa P, Simoens CM. Laparoscopic gastric banding as revisional procedure to failed vertical gastroplasty Obes Surg. 2009;
19(11):1477-80

31. Elazary R, Hazzan D, Appelbaum L, Rivkind Al, Keidar A. Feasibility of sleeve gastrectomy as a revision operation for failed silastic ring vertical gastroplasty Obes Surg. 2009 May;19(5):645-9.

32. Pok EH,Lee WJ,Ser KH,etal. Laparoscopic sleeve gastrectomy in Asia: long term outcome and revisional surgery. Asian J Surg 2016;39:21-8.

33. Israel A, Sebbag G, Fraser D. Nutritional Behavior as a Predictor of Early Success after Vertical Gastroplasty. Obes Surg. 2005;15(1):88-94.

34. Wölfel R, Günther K, Rümenpapf G, Koerfgen P, Husemann B. Weight Reduction After Gastric Bypass and Horizontal Gastroplasty for Morbid Obesity. Eur J Surg. 1994;160:219-25. 